\title{
The Inevitable Consequences of Nuclear Armament: An Urgent Call for Nuclear Disarmament
}

\author{
Ignatius Nnaemeka Onwuatuegwu ${ }^{1} *$ and Nkemjika Bernardine Nwagu ${ }^{2}$ \\ ${ }^{1}$ Dept. of Philosophy, Faculty of Arts, Nnamdi Azikiwe University Awka, Nigeria; and ${ }^{2}$ Dept. of Entrepreneurship, Faculty \\ of Management Sciences, University of Benin, Nigeria. \\ *Correspondence: frig2014@gmail.com (Ignatius Nnaemeka Onwuatuegwu, Dept. of Philosophy, Faculty of Arts, Nnamdi \\ Azikiwe University Awka, Nigeria).
}

\begin{abstract}
Advancement in technology and growth in human wisdom and knowledge has become a boom and at the same time, a bane to the continued survival of mankind. Despite been born free, mankind has become enslaved to the products of their hands. The invention of weapons of human destruction (nuclear weapons), which remains the most destructive form of armory ever created, with the capacity to inflict a large-scale disaster in the shortest time, in just a strike. These weapons and their mass destructive capacity were first experienced in the Hiroshima and Nagasaki atomic bombing in the year 1945, from that moment on the world, have seen an increase in nuclear testing, nuclear armory, and nuclear race among nuclear-weapon states. The mere presence of nuclear weapons poses a serious threat to the earth's environment and its inhabitants. Many islands have become inhabitable or declared a no-go zone due to the high presence of radiation and radioactivity in those places which is a direct result of years of nuclear testing. As a consequence, many people have been displaced from their ancestral lands, while some victims have lost their time to radiation-induced diseases such as cancer and its various variation. This article, therefore, will focus on the global threat to humanity posed by nuclear armament.
\end{abstract}

Keywords: Nuclear armament, Weapons, Threat to humans, Disarmament, Environment, and Global peace.

\section{INTRODUCTION:}

Advancement in technology and growth in human wisdom and knowledge has become a boom and at the same time, a bane to the continued survival of mankind. Despite the freedom that intrinsically belongs to man from birth, mankind has gradually become the slave of the products of their hands (Arthur, 1990). A typical example is the invention of nuclear weapons, which remains the most destructive form of armoury ever created, which has the capacity to inflict a large scale disaster in the shortest time, in just a strike. Nuclear weapons, together with its mass destructive capacity were first experienced in the Hiroshima and
Nagasaki atomic bombing in the year 1945 (Internet source, 2020). From that moment on the human universe has seen an increase in nuclear testing, nuclear armoury and nuclear race among nuclear-weapon states.

Thus, accounting for the global presence of estimated 14,500 nuclear weapons as well as more than 2,000 nuclear tests (Internet source, 2020). It is quite striking that the use of nuclear weapon brought about the end of the World War II, and then ushered in the era of cold war, typified by nuclear arm race between nations (Remus, 2014), as demonstrated in the cold war that 
ensued between the United States and Soviet Union, which exposed humanity to major humanistic crisis which could results from any mistake in the application of these weapons-human error. Examples include the miscalculation in a bombing test in Namu Island, the 1986 nuclear accident in the Chernobyl power plant, and 1979, the incidence in the Three Mile Island nuclear power station in Harrisburg, Pennsylvania which led to the displacement of people from their ancestral lands, damage to soil, marine life and increased vulnerability to life-threatening diseases.

The mere existence of these weapons of human destruction in today's world, to no small extent, poses severe threats to the security and existence of mankind on the faces of the earth.

\section{Nuclear Armament: A global threat to Human Existence}

Nuclear detonation has been observed to have both immediate and long term (remote) impact on the health of inhabitants of the affected city region. Following the detonation itself, of a nuclear weapon, the explosion quickly facilitates the release blast, waves, heat, and radiation. The heat which is the consequence the explosion, necessarily results to the immediate vaporization of humans and animals within the vicinity or even $3 \mathrm{~km}$ distance from the affected zone, as the earth temperature is heated up to an approximate of $7000^{\circ} \mathrm{C}$, while some people will be vaporized, others will suffer terrible full-thickness skin burn. From looking at the explosion, individuals could suffer a temporary or a lifetime eye damage. The death toll and casualty rate also increase due to collapse of physical infrastructures which could in turn lead to compound fractures, ruptured fractures and penetrative injuries or even death (Hasan et al., 2020; International Committee of the Red Cross, 2013).

Exposure to radiation and the fallout of radio-active waves can possibly result to a dysfunction of the central nervous system. It could also inhibit the human body from recreating new blood cells, and increased vulnerability to life - threatening infections. Moreso, the damage of the gastrointestinal tracts could equally result from such a situation. The catastrophic nature of the aftermath of a nuclear detonation is reflected in its ability to negatively impact the health of people locat-

UniversePG I www.univcersepg.com ed outside the immediate proximity of the affected area. Majority of the affected population may not even be aware of the fact that they have been exposed to doses of radiation until they start showing off clinical signs of sickness resulting from radiation such as bleeding, itching, sore skin, vomiting, burning eyes, diarrhoea or even wounds that fails to heal (British Medical Association, 1983). The long-term health impact is seen in increased vulnerability to various forms of cancer, such as lung cancer, cancer of the breast, cancer of the thyroid and cancer of the blood.

Practically speaking, the atomic bombing of Hiroshima and Nagasaki despite over 50 years of its occurrence has continued to impact the health of the residents of Hiroshima and Nagasaki negatively. In a report from a committee (The Committee for the Compilation of Materials on Damage Caused by the Atomic Bombs in Hiroshima and Nagasaki, 1981), it was established that mortalities accrued from the event of 1945 in Hiroshima and Nagasaki has continued to increase over the years, specifically, by 1950 , mortalities rose from earlier reported 150,000 and 75,000 to 200,000 and 140,000 respectively. There was also a conspicuous escalation in the number of cases of leukaemia from late 1945, and reached an all-time high in the mid1950s, before decreasing to a lower rate. Despite the reduction in occurrence, the incidence of Leukemia is still at an elevated level. There was also an increase in the vulnerability to other forms of cancer (breast, colon, lungs, and oesophagus), radiation-related diseases and death have been recorded among the elderly survivors of the blast. The earth's environment has not been spared too from the harmful effect of a nuclear weapon. In the present society, there have been increased contamination of the various aspect of the atmospheric environment (land, Air and Sea) with radioactive waste (Remus, 2014).

Such acts as atmos-pheric nuclear weapons testing often result to the letting out of radioactive isotopes, (especially 14C, 137Cs, and 90Sr) into the atmosphere (UNSCEAR, 1993), Many testing site examples include Fukushima, Harrisburg, Bikini Atoll, Hanford, Nevada, Chernobyl Exclusion Zone, while some are known to have radia-tion exposure which is far greater than the permissible levels, some have been declared an "A no go zone" (Bordner et al., 2016). 


\section{CONCLUSION:}

The very existence of the weapons of human destruction puts the stability and peace of the human world into jeopardy. In events where these weapons find their way into the wrong hands the aftermath would be disastrous. With a recent hike in nuclear projects among countries, there is an imminent fear of a nuclear war outbreak; all this puts humanity at risk, human life can only thrive in a peaceful and hazardfree environment. It, therefore, becomes imperative for global leaders to pursue and intensify their efforts towards nuclear disarmament to truly secure protection for human life globally.

\section{ACKNOWLEDGEMENT:}

In the first instance, my unceasing gratitude and unreserved thanks go to the Father of all lives. May his Holy name be blessed forever more, amen. Just as a tree cannot make a forest, the completion of this work could not have been a reality if not for the invaluable support and wonderful co-operation and contributions of the co-author, N. B. Nwagu. I hereby salute her with the highest form of salutation. Very important to mention is the support and encouragement received from the entire members of Onwuatuegwu and Nwagu family. You really created the enabling atmosphere that facilitated the successful and credible completion of this work. May the most benevolent God in his infinite magnanimity bless you and keep you.

\section{CONFLICTS OF INTEREST:}

The researchers herein declare and affirm that there is no potential conflict of interest as regards the present study.

\section{REFERRENCES:}

1) Arthur, K. (1990). Quoted in the UNESCO Courier, September 1990. Pp. 20.

https://en.unesco.org/courier/september-1990

2) Bordner, A. S. et al. (2016). "Measurement of background gamma radiation in the northern
Marshall Islands". Proc. Natl. Acad. Sci. USA. 113(25), Pp.6833-6838. https://doi.org/10.1073/pnas.1605535113

3) British Medical Association (BMA), (1983). The Medical Effects of a Nuclear War. John Wiley \& Sons, Chichester,. Pp.103-104.

4) Hasan MR, Rahman KMR, Shohag MR, and Uddin MM. (2020). Efficient water management and selection of cooling system for future NPP in Bangladesh, Int. J. Mat. Math. Sci., 2(6), 93-98.

https://doi.org/10.34104/ijmms.020.093098

5) International Committee of the Red Cross, (2013). The Effects of Nuclear Weapons on Human Health. Geneva, Switzerland. https://www.icrc.org/en/doc/assets/files/2013/41 32-1-nuclear-weapons-human-health-2013.pdf

6) Remus Pra va lie, (2014). Nuclear Weapons Tests and Environmental Consequences: A Global Perspective. Royal Swedish Academy of Sciences.

7) The Committee for the Compilation of Materials on Damage Caused by the Atomic Bombs in Hiroshima and Nagasaki: the Physical, Medical, and Social Effects of the Atomic Bombings, Basic Books Inc, New York, 1981.

8) United Nations Office for Disarmament Affairs, (2018). Nuclear Weapons, Online. February $22,2020$.

https://www.un.org/disarmament/wmd/nuclea/

9) UNSCEAR, (1993). Report to the general assembly (Annex B - Exposures from manmade sources of radiation). February 22, 2020.

10) War History, (2017). The Lasting Effects of the Atomic Bombing of Hiroshima and Nagasaki. 20 February 2020.

https://www.warhistoryonline.com/world-warii/lasting-effects-wwii-atomic-bombings-mm.ht $\underline{\mathrm{ml}}$

Citation: Onwuatuegwu IN., and Nwagu NB. (2021). The inevitable consequences of nuclear armament: an urgent call for nuclear disarmament, Br. J. Arts Humanit., 3(4), 103-105. https://doi.org/10.34104/bjah.02101030105 @ () 